\title{
Recommended nitrogen rates and the verification of effects based on leaf SPAD readings of rice
}

\author{
Wenfeng Hou $^{1}$, Juan Shen ${ }^{1}$, Weitao Xu ${ }^{1}$, Muhammad Rizwan Khan ${ }^{2}$, Yin Wang ${ }^{1}$, Xue Zhou $^{1}$, Qiang Gao ${ }^{1}$, Behzad \\ Murtaza $^{3}$, Zhongqing Zhang ${ }^{\text {Corresp. } 1}$ \\ ${ }^{1}$ Key Laboratory of Soil Resource Sustainable Utilization for Jilin Province Commodity Grain Bases/College of Resources and Environmental Science, Jilin \\ Agricultural University, Changchun, Jilin, China, Changchun, China \\ 2 Soil and Environmental Sciences Division, Nuclear Institute for Agriculture and Biology (NIAB), Faisalabad, Pakistan, Faisalabad, Pakistan \\ 3 Department of Environmental Sciences, COMSATS University Islamabad, Vehari Campus, Pakistan., Vehari, Pakistan \\ Corresponding Author: Zhongqing Zhang \\ Email address: 447000257@qq.com
}

Modern rice production systems need a reliable, easy-to-use, efficient, and environmentally-friendly method to determine plant nitrogen $(\mathrm{N})$ status, predict grain yield, and optimize $\mathrm{N}$ management. We conducted field experiments to determine the influence of different $\mathrm{N}$ rates on Soil Plant Analysis Development (SPAD) readings of rice leaves. We also performed field validations to evaluate the grain yield and $\mathrm{N}$ use efficiency under recommended $\mathrm{N}$ rates. Our results showed that leaf SPAD readings increased as $\mathrm{N}$ rates increased. We applied the recommended $\mathrm{N}$ based on the relationships between the $\mathrm{N}$ rates and leaf SPAD readings at the tillering and booting stages. The recommended $\mathrm{N}$ decreased $\mathrm{N}$ rates and improved $\mathrm{N}$ use efficiency without sacrificing grain yield. When compared to farmer practices (FP), the recommended $\mathrm{N}$ rates of optimization (OPT) decreased by $5.8 \%$ and $10.0 \%$, respectively. In comparison with FP, the $\mathrm{N}$ agronomic efficiency of OPT increased by 5.8 and $10.0 \%$ while the partial factor productivity of $\mathrm{N}$ increased by 6.0 and $14.2 \%$, respectively. The SPAD meter may be a reliable tool to analyze the $\mathrm{N}$ in rice, estimate real-time $\mathrm{N}$ fertilization, and improve $\mathrm{N}$ use efficiency. 
1 Recommended nitrogen rates and the verification of effects based on leaf SPAD readings of rice

3 Wenfeng Hou ${ }^{1}$, Juan Shen ${ }^{1}$, Weitao Xu${ }^{1}$, Muhammad Rizwan Khan ${ }^{2}$, Yin Wang ${ }^{1}$, Xue Zhou ${ }^{1}$, Qiang Gao ${ }^{1}$,

4 Behzad Murtaza ${ }^{3}$, Zhongqing Zhang ${ }^{1 *}$

$5 \quad{ }^{1}$ Key Laboratory of Soil Resource Sustainable Utilization for Jilin Province Commodity Grain Bases/College

6 of Resources and Environmental Science, Jilin Agricultural University, Changchun, Jilin, China

$7 \quad{ }^{2}$ Soil and Environmental Sciences Division, Nuclear Institute for Agriculture and Biology (NIAB), Faisalabad,

8 Pakistan

$9 \quad{ }^{3}$ Department of Environmental Sciences, COMSATS University Islamabad, Vehari Campus, Pakistan.

Corresponding author:

Zhongqing Zhang

Street Address: Changchun, Jilin Province, 130118, China

E-mail address: 447000257@qq.com

10 ABSTRACT 
11 Modern rice production systems need a reliable, easy-to-use, efficient, and environmentally-

12 friendly method to determine plant nitrogen $(\mathrm{N})$ status, predict grain yield, and optimize $\mathrm{N}$

13 management. We conducted field experiments to determine the influence of different $\mathrm{N}$ rates on

14 Soil Plant Analysis Development (SPAD) readings of rice leaves. We also performed field validations to evaluate the grain yield and $\mathrm{N}$ use efficiency under recommended $\mathrm{N}$ rates. Our results showed that leaf SPAD readings increased as $\mathrm{N}$ rates increased. We applied the recommended $\mathrm{N}$ based on the relationships between the $\mathrm{N}$ rates and leaf SPAD readings at the tillering and booting stages. The recommended $\mathrm{N}$ decreased $\mathrm{N}$ rates and improved $\mathrm{N}$ use efficiency without sacrificing grain yield. When compared to farmer practices (FP), the recommended $\mathrm{N}$ rates of optimization (OPT) decreased by $5.8 \%$ and $10.0 \%$, respectively. In comparison with FP, the $\mathrm{N}$ agronomic efficiency of OPT increased by 5.8 and $10.0 \%$ while the partial factor productivity of $\mathrm{N}$ increased by 6.0 and $14.2 \%$, respectively. The SPAD meter may be a reliable tool to analyze the $\mathrm{N}$ in rice, estimate real-time $\mathrm{N}$ fertilization, and improve $\mathrm{N}$ use efficiency.

\section{INTRODUCTION}

Rice (Oryza sativa L.) is one of the most important cereal crops and food sources in the world.

Rice yields must be increased in order to meet the food demands of ever-growing populations

(Guo et al., 2019) and synthetic fertilizers, particularly nitrogen (N), play a vital role in improving rice yields. $\mathrm{N}$ is arguably the most important limiting factor, aside from water, for rice production. Global rice yield significantly increased with rising $\mathrm{N}$ rates. In current agricultural systems, most farmers apply $\mathrm{N}$ in excess relative to the actual crop's needs to harvest more grain. 
32 This practice leads to low $\mathrm{N}$ use efficiency due to high $\mathrm{N}$ losses through runoff, denitrification,

33 leaching, volatilization, and a high risk of environmental contamination (Zeng et al., 2012; Liu et

34 al., 2013; Bodirsky et al., 2014; Xiong, et al., 2015). The average $\mathrm{N}$ use in China's rice

35 production has been reported to be significantly higher than the global average (Chen et al.,

36 2011). It is imperative to optimize $\mathrm{N}$ fertilizer use to prevent damage to crops and the

37 environment, improve $\mathrm{N}$ use efficiency, and maintain production system sustainability. The use

38 of controlled-release $\mathrm{N}$ fertilizers, nitrification inhibitors, and deep conventional urea placement

39 are methods that have been tested to prevent $\mathrm{N}$ losses and improve $\mathrm{N}$ use efficiency. $\mathrm{N}$ fertilizer

40 may be reduced by 12-50\% without sacrificing grain yield (Qiao et al., 2012; Wang et al., 2012).

41 It is important to accurately measure leaf $\mathrm{N}$ content because it plays a crucial role in the

42 growth and development of rice. Chemical analysis of leaf $\mathrm{N}$ content has been used to monitor $\mathrm{N}$

43 status and estimate the demand for $\mathrm{N}$ fertilizer (Ziadi et al., 2008; Tian et al., 2011). The current

44 method is destructive and time-consuming so finding an indirect method to measure leaf $\mathrm{N}$

45 content is of great importance (Uddling et al., 2007; Yuan et al., 2016). Leaf N content is

46 strongly correlated with chlorophyll content (Wang et al., 2014; Yang et al., 2014; Kalaji et al.,

47 2017), thus leaves' spectral characteristics may be used to guide N fertilizer use. Soil Plant

48 Analysis Development (SPAD) readings can be used to assess the in situ leaf N status based on

49 light transmitted through leaves. The use of SPAD readings to monitor rice $\mathrm{N}$ status has been

50 used to improve grain yield and $\mathrm{N}$ use efficiency over the past two decades (Khurana et al., 2007;

51 Huang et al., 2008; Li et al., 2009; Hou et al., 2020). Available N affects the chlorophyll content

52 of the leaf, as $\mathrm{N}$ is one of the key elements of chlorophyll. Errecart et al. (2012) observed a close 
53

54

correlation between chlorophyll content and leaf $\mathrm{N}$ concentration. SPAD may reflect the plant leaves' N status and is simple, quick, reliable, and harmless (Li et al., 2009; Xiong, et al., 2015; Akhter et al., 2016; Yuan et al., 2016). There has been a significant correlation between SPAD readings for dry mass leaves' $\mathrm{N}$ content and grain yield (Ramesh et al., 2002; Parvizi et al., 2004), indicating that SPAD readings may help determine optimum $\mathrm{N}$ application rates.

We sought to: (1) estimate the relationship between leaf SPAD readings and recommended N rates; (2) investigate the yield effects and $\mathrm{N}$ use efficiency of recommended $\mathrm{N}$ rates based on leaf SPAD readings.

\section{MATERIALS AND METHODS}

\section{Experimental Site}

We conducted two field experiments and two verification experiments $\left(45.09^{\circ} \mathrm{N}, 124.92^{\circ} \mathrm{E}\right.$;

$45.13^{\circ} \mathrm{N}, 124.89^{\circ} \mathrm{E}$ ) in 2008 and 2009 involving different $\mathrm{N}$ rates in the Songyuan, Jilin Province, which is one of the major regions for japonica rice production in China. Both testing sites had black soils. The physicochemical properties of the experimental soils were $\mathrm{pH} 8.3$ and $\mathrm{pH} 7.2$ (soil: water $=1: 2.5$ ), organic matter content $12.6 \mathrm{~g} \mathrm{~kg}^{-1}$ and $18.7 \mathrm{~g} \mathrm{~kg}^{-1}$, total $\mathrm{N} 1.4 \mathrm{~g} \mathrm{~kg}^{-1}$ and $2.1 \mathrm{~g} \mathrm{~kg}^{-1}$, Olsen-P $12.2 \mathrm{mg} \mathrm{kg}^{-1}$ and $9.0 \mathrm{mg} \mathrm{kg}^{-1}$, and readily available $\mathrm{K} 98.4 \mathrm{mg} \mathrm{kg}^{-1}$ and $49.0 \mathrm{mg} \mathrm{kg}^{-1}$, respectively.

\section{Weather parameters}

Songyuan has a mid-temperate continental monsoon climate. The annual average temperature, annual average sunshine, frost-free period, and annual precipitation in the rice-growing seasons were $5.1^{\circ} \mathrm{C}, 2,878$ hours, 140 days, and $450 \mathrm{~mm}$, respectively. Figure 1 shows the daily 
74

75

temperature and precipitation during the rice-growing season. The total precipitation during the rice-growing season was 387 and $218 \mathrm{~mm}$ in each field.

\section{Experimental design and managements}

In 2008 , we conducted two field trials using seven nitrogen $(\mathrm{N})$ rates $(0,45,90,135,180,225$, and $270 \mathrm{~kg} \mathrm{~N} \mathrm{ha}^{-1}$ ) in two different fields in the same location. We used the same planting pattern in both fields. We then used a randomized complete block design with three replicates. Nitrogen $(\mathrm{N})$, phosphorus $(\mathrm{P})$, and potassium $(\mathrm{K})$ were applied as urea $(46 \% \mathrm{~N})$, superphosphate $\left(12 \%, \mathrm{P}_{2} \mathrm{O}_{5}\right)$, and potassium chloride $\left(60 \% \mathrm{~K}_{2} \mathrm{O}\right)$, respectively. Nitrogen was applied in three doses: $1 / 2$ dose in the form of basal fertilizer 1 day before transplanting, $1 / 4$ dose in the first topdressing 7 days after transplanting, and $1 / 4$ dose as the second top dressing at the panicle initiation stage. Demonstrative experiments were conducted in 2009 close to where we experimented with different $\mathrm{N}$ rates. The two demonstration experiments were comprised of three treatments: zero $\mathrm{N}(\mathrm{CK})$, farmer practice $\left(\mathrm{FP}, 180 \mathrm{~kg} \mathrm{~N}^{-1}\right.$ ), and optimization (OPT, $\mathrm{N}$ rate was recommended based on leaf SPAD readings).

Phosphorous was applied at a uniform rate of $90 \mathrm{~kg} \mathrm{P}_{2} \mathrm{O}_{5}$ ha-1 $^{-1}$ in each experimental plot as a basal dressing one day before transplanting. We applied $90 \mathrm{~kg} \mathrm{~K}_{2} \mathrm{O} \mathrm{ha}{ }^{-1}$ in each experimental plot: $70 \%$ was applied as a basal dressing 1 day before transplanting; $30 \%$ was applied as a top dressing at the panicle initiation stage. The fertilizers were distributed to each plot and then mixed evenly by a rake. Each plot measured $30 \mathrm{~m}^{2}(6 \mathrm{~m} \times 5 \mathrm{~m})$.

We used the hybrid rice Jigeng 88 with a growth period of 145 days in these experiments.

This rice variety is widely planted in the Northeast China Plain basin. Seedlings were raised in a 
95

96

97

seedbed. Seeds were sown on May 3rd and May 22nd, and seedlings were transplanted on June 3rd and June 29th in 2008 and 2009, respectively, at the four-leaf-stage. We planted a single plant per hill; hills were spaced $30 \mathrm{~cm} \times 20 \mathrm{~cm}$ and followed the local agricultural technology department's recommended practices. Rice seeds and plants were treated with the same fungicides, insecticides, and herbicides to avoid yield losses. We irrigated and performed other agronomic practices according to high-yield and standard protocols (Zhang et al., 2009).

\section{Soil sample collection and analysis}

Surface soil $(0-20 \mathrm{~cm})$ samples were randomly collected with a drag-type drill from five points in the experimental field two days before transplanting on a sunny day. The composite soil samples were air-dried, ground, and passed through $1 \mathrm{~mm}$ and $0.149 \mathrm{~mm}$ sieves to determine soil physicochemical characteristics. The soil $\mathrm{pH}$, organic matter, total $\mathrm{N}$, available $\mathrm{P}$, and exchangeable K were determined following Bao (2000)'s method.

\section{SPAD reading}

A total of six plants placed in the center of each plot were marked after transplanting. A chlorophyll meter (Soil Plant Analysis Development, SPAD-502) was used for taking the SPAD reading measurements of the uppermost fully expanded leaves at the tillering stage, jointing stage, booting stage, heading stage, flowering stage, and filling stage. Three SPAD readings per leaf were taken around the midpoint and again $30 \mathrm{~mm}$ away on both sides of the midpoint. Each plot's SPAD reading was determined by taking the average of 18 readings (Peng et al., 1993).

\section{Plant harvest}


115 Plants were harvested on September $15^{\text {th }}$ and October 1st in two consecutive years. Each plot's 116 grain yield was determined from the $15 \mathrm{~m}^{2}$ area by measuring from the center of each plot and 117 was adjusted to $14 \%$ moisture.

\section{Calculations}

119 Nitrogen use efficiency was expressed in terms of $\mathrm{N}$ agronomic efficiency (NAE) and partial factor productivity of N (PFPN), which were calculated as follows (Jian et al. 2014): NAE $\left(\mathrm{kg} \mathrm{kg}^{-1}\right)=($ grain yield of N-fertilized plot - grain yield of zero-N plot) / applied $\mathrm{N}$ rate. PFPN $\left(\mathrm{kg} \mathrm{kg}^{-1}\right)=$ grain yield of $\mathrm{N}$-fertilized plot / applied $\mathrm{N}$ rate.

\section{Statistical analysis}

All figures were drawn using Origin 8.0 software (Origin Lab, Massachusetts, USA). The means were separated using one-way analysis of variance with a Tukey test at a 5\% probability level using SPSS 17.0 software (SPSS Inc., Chicago, USA).

\section{RESULTS}

\section{Effects of $\mathrm{N}$ rates on leaf SPAD readings}

The leaf SPAD readings first increased and then decreased during the reproductive period (Fig.

2). Higher $\mathrm{N}$ rates significantly increased the leaf SPAD readings. The N0 treatment resulted in the lowest leaf SPAD readings, while N270 showed the highest leaf SPAD readings in both years. In 2008, N270 leaf SPAD readings increased by $31.5-42.8 \%$ in experiment 1 and by $27.2-56.2 \%$

133 in experiment 2 when compared with N0. 
135 at the tillering and booting stages in both experiments (Fig. 3). The following linear correlations

136 were found between $\mathrm{N}$ rates and leaf SPAD readings at the tillering stages in experiments 1 and

137 2, respectively:

138

139

140

141

142

143

144

145

146

147

148

149

150

151

152

153

154

155

$$
\begin{aligned}
& Y=0.0833 X+30.4(a) \\
& Y=0.1006 X+29.8(b)
\end{aligned}
$$

The following linear correlations were found between the $\mathrm{N}$ rates and leaf SPAD readings at the booting stages in experiments 1 and 2, respectively:

$$
\mathrm{Y}=0.0568 \mathrm{X}+30.5(\mathrm{c})
$$

$$
\mathrm{Y}=0.0480 \mathrm{X}+30.8(\mathrm{~d})
$$

\section{Grain yield}

The grain yield quickly responded to $\mathrm{N}$ rates in both experiments (Fig. 4). An increase in $\mathrm{N}$ rates significantly improved the grain yield relative to the N0 treatment. However, further increases in $\mathrm{N}$ rates caused significantly different yield responses. The grain yield decreased when the $\mathrm{N}$ rate was higher than $235 \mathrm{~kg} \mathrm{ha}^{-1}$ in experiment 1 (Fig. 4a). The relationship between the $\mathrm{N}$ rates and grain yield was unitary conic. In contrast, the grain yield increased with an increase in $\mathrm{N}$ rates and then became stagnant as the $\mathrm{N}$ rate rose beyond $195 \mathrm{~kg} \mathrm{ha}^{-1}$ in experiment 2 (Fig. $4 \mathrm{~b}$ ).

\section{Recommended $\mathrm{N}$ rates at the tillering and booting stages}

The recommended $\mathrm{N}$ rates at the tillering and booting stages based on leaf SPAD readings are shown in Tables 1 and 2, respectively. The $\mathrm{N}$ supply increased the leaf SPAD readings in experiments 1 and 2 by $21.3 \%$ and $22.7 \%$ at the tillering stage, and by $27.1 \%$ and $13.6 \%$ at booting stage, respectively, compared with $\mathrm{CK}$. The optimum $\mathrm{N}$ rate was $235 \mathrm{~kg} \mathrm{ha}^{-1}$ in 
156

157 158 159 160 161

experiment 1 and $195 \mathrm{~kg} \mathrm{ha}^{-1}$ in experiment 2 in 2008 based on the relationship between $\mathrm{N}$ rates and grain yield (Figure 4). Basal dosages in the OPT treatments were based on the N usage mode; in experiment 1 the dosage was $78 \mathrm{~kg} \mathrm{~N} \mathrm{ha}^{-1}$, in experiment 2 the dosage was $65 \mathrm{~kg} \mathrm{~N} \mathrm{ha}^{-1}$, and in the FP treatments the dosage was $90 \mathrm{~kg} \mathrm{~N} \mathrm{ha}^{-1}$. At the tillering stage, the leaf SPAD readings in the OPT treatments were 33.0 in experiment 1 and 32.6 in experiment 2 , respectively. The optimum leaf SPAD readings at the tillering stage in experiments 1 and 2 were 36.9 and 36.3, respectively. These findings were based on the relationship between the $\mathrm{N}$ rates and leaf SPAD readings at the tillering stage (Fig. $3 \mathrm{a} \& \mathrm{~b}$ ). $\mathrm{N}$ rate supply in experiments 1 and 2 were determined to be $12.0 \mathrm{~kg} \mathrm{ha}^{-1}$ and $9.7 \mathrm{~kg} \mathrm{ha}^{-1}$, respectively, for the unit increase in leaf SPAD readings. The recommended $\mathrm{N}$ rates at the tillering stage in experiment 1 and 2 were 46.8 and $35.9 \mathrm{~kg} \mathrm{ha}^{-1}$, respectively (Table 1$)$.

Similarly, leaf SPAD readings of the OPT treatments at the booting stage were 36.8 in experiment 1 and 34.7 in experiment 2. The optimum SPAD readings in experiments 1 and 2 were 39.4 and 37.1, respectively, based on the relationship between the $\mathrm{N}$ rates and leaf SPAD readings at the booting stage (Fig. $3 \mathrm{c} \& \mathrm{~d}$ ). The $\mathrm{N}$ supply rates in experiments 1 and 2 were determined to be 17.2 and $21.5 \mathrm{~kg} \mathrm{ha}^{-1}$, respectively, for the unit increase in leaf SPAD reading.

Hence, the recommended $\mathrm{N}$ rates at the tillering stage in experiments 1 and 2 were 44.7 and 51.6 $\mathrm{kg} \mathrm{ha}^{-1}$, respectively (Table 2).

\section{Grain yield and $\mathbf{N}$ use efficiency}

The grain yield and $\mathrm{N}$ use efficiency of the demonstration experiments are shown in Table 3. Compared with CK, the $\mathrm{N}$ supply increased grain yield by 347.1 and $102.5 \%$ in experiments 1 
177 and 2, respectively. However, there was no significant difference between the yield of FP and

178 OPT recorded. The recommended $\mathrm{N}$ rates on the basis of leaf SPAD readings were 169.5 and

$179152.5 \mathrm{~kg} \mathrm{ha}^{-1}$ in experiments 1 and 2, respectively. Compared with $\mathrm{FP}$, the recommended $\mathrm{N}$ rates

180 of OPT decreased by $5.8 \%$ in experiment 1 and $15.3 \%$ in experiment 2 . Moreover, the OPT's

181 NAE and PFPN were higher than FP's in both experiments. The OPT's NAE increased by 5.8

182 and $10.0 \%$ while PFPN increased by 6.0 and $14.2 \%$ compared to FP in experiments 1 and 2 ,

183 respectively.

184 DISCUSSION

185 We determined $\mathrm{N}$ based on non-destructive leaf SPAD readings, which may help to decrease $\mathrm{N}$ rates. The recommended $\mathrm{N}$ rates based on leaf SPAD readings improved the $\mathrm{N}$ use efficiency of rice without sacrificing grain yield. SPAD readings gradually increased as $\mathrm{N}$ rates rose (Fig. 2).

SPAD readings are increasingly used as a quick and non-destructive method to monitor crop

$\mathrm{N}$ content, growth status, and to predict grain yield. Maiti and Das (2006) reported that a SPAD

reading of 37 as the threshold works well for $\mathrm{N}$ fertilizer application in wheat. There is a significant correlation between the chlorophyll measurement obtained using a SPAD meter and

leaf $\mathrm{N}$ content in maize (Yu et al., 2010). Cabangon et al. (2011) and Xiong et al. (2015)

determined that there was a close relationship between leaf SPAD readings and leaf $\mathrm{N}$ content

per leaf area. Arregui et al. (2006) reported that the absolute or normalized relationships between

the relative yield and grain $\mathrm{N}$ content with SPAD meter readings following a quadratic model and the Cate-Nelson statistical procedure. Monostori et al. (2016) indicated that SPAD readings 
198

199

200

201

202

203

204

205

206

207

208

209

210

211

212

213

214

215

216

217

218

be used to assess cotton $\mathrm{N}$ nutrition status and estimate cotton biomass. Edalat et al. (2019) reported that the combination of leaf $\mathrm{N}$ and SPAD data may become a tool to manage corn field $\mathrm{N}$ status and predict grain yield. A SPAD reading of 38 could be used to optimize $\mathrm{N}$ management by maintaining high grain yield and reducing $\mathrm{N}$ input by approximately $25 \% \mathrm{~N}$ (Cabangon et al., 2011), which was similar to our results.

Low $\mathrm{N}$ use efficiency may be caused by excessive $\mathrm{N}$ applications coupled with the inefficient splitting of $\mathrm{N}$ doses (Singh et al., 2010). The global N demand is expected to increase by 100$110 \%$ relative to 2005 usage levels, and the use of $\mathrm{N}$ is projected to increase from $100 \mathrm{Mt}$ to 225 250 Mt by 2050 (Tilman et al., 2011), resulting in increased $\mathrm{N}$ losses, decreased economic benefits, and a decline in environmental health (Peng et al., 2006). It is important to determine the appropriate $\mathrm{N}$ rate for sustainable and productive rice production $(K u$ et al., 2016). $\mathrm{N}$ management practices should be easy to use, reliable, efficient, and environment friendly. SPAD readings would allow farmers to routinely monitor the leaf $\mathrm{N}$ status, adjust fertilization rates and times, avoid excessive $\mathrm{N}$ application, reduce $\mathrm{N}$ losses, and enhance $\mathrm{N}$ use efficiency.

The SPAD meter is a useful tool to determine plants' $\mathrm{N}$ status but it might have limitations. The SPAD readings are taken from a small leaf area $\left(6 \mathrm{~mm}^{2}\right)$ and require many repetitions before ascertaining the leaf $\mathrm{N}$ status (Rorie et al., 2011; Wang et al., 2014). In contrast, the leaf $\mathrm{N}$ contents could be determined using the micro-Kjeldahl digestion and distillation method (Yang et al., 2003), which is a destructive sampling method but is more accurate. The SPAD reading could be affected by many factors like leaf thickness, growth stages, genotype, chloroplast movement, irradiance, and field-to-filed variability of soil N supply (Samborski et al., 2009; 
219 Naus et al., 2010; Singh et al., 2010; Kalaji et al., 2017). The infestation of plants with diseases 220 or insects may also affect the results of the SPAD meter (Singh et al., 2010). This equipment 221 requires qualified personnel to take leaf samples following a rigorous methodology (Reyes et al., 222 2017) and the measurements may deliver incorrect data if the plants are deficient in nutrients 223 other than N (Kalaji et al., 2017). Previous studies have shown that nutrient deficiencies 224 influenced the photosynthetic yield of PSII (Redillas et al., 2011; Msilini et al., 2013; Kalaji et 225 al., 2014). It was suggested that the chlorophyll fluorescence could be used as a noninvasive method to detect nutrient deficiency that is more precise and sensitive (Goltsev et al., 2016;

227 Kalaji et al., 2018; Horaczek et al., 2020).

\section{CONCLUSION}

Our study determined the positive effects of $\mathrm{N}$ rates on rice leaf SPAD readings, which can help determine more precise $\mathrm{N}$ application rates. The recommended $\mathrm{N}$ rates of OPT decreased by $5.8 \%$ and $15.3 \%$ in comparison with FP in the two experiments, respectively, based on leaf SPAD readings, when compared with FP doses. Similarly, the NAE of OPT increased by $5.8 \%$ and $10.0 \%$, while PFPN increased by $6.0 \%$ and $14.2 \%$, respectively, compared with FP. The SPAD meter allows farmers to monitor rice $\mathrm{N}$ status routinely, rapidly, and accurately. This may improve the timing and dose of $\mathrm{N}$ applications, reduce $\mathrm{N}$ losses, and improve $\mathrm{N}$ use efficiency.

\section{REFERENCES}

Akhter MM, Hosain A, Timsina J, Teixeira da Silva A, Islam MS. 2016. Chlorophyll meter Journal of Plant Production 10:289-302 DOI 10.22069/IJPP.2016.2898. 
240

241

242

243

244

245

246

247

248

249

250

251

252

253

254

255

256

257

258

259

260

Arregui LM, Lasa B, Lafarga A, Iraneta I, Barja E, Quemada M. 2006. Evaluation of chlorophyll meters as tools for $\mathrm{N}$ fertilization in winter wheat under humid Mediterranean conditions. European Journal of Agronomy 24:140-148 DOI 10.1016/j.eja.2005.05.005.

Bao S. 2000. Soil Agricultural-Chemical Analysis. China Agric. Press, Beijing.

Bodirsky BL, Popp A, Lotze-Campen H, Dietrich JP, Rolinski S, Weindl I, Schmitz C, Muller C, Bonsh M, Humpenoder F, Biewald A, Stevanovic M. 2014. Reactive nitrogen requirements to feed the world in 2050 and potential to mitigate nitrogen pollution. Nature Communications 5:3858 DOI 10.1038/ncomms4858.

Cabangon RJ, Castillo EG, Tuong TP. 2011. Chlorophyll meter-based nitrogen management of rice grown under alternate wetting and drying irrigation. Field Crops Research 121:136146 DOI 10.1016/J.FCR.2010.12.002.

Chen J, Huang Y, Tang Y. 2011. Quantifying economically and ecologically optimum nitrogen rates for rice production in south-eastern China. Agriculture, Ecosystems and Environment 142:195-204 DOI 10.1016/j.agee.2011.05.005.

Edalat M, Naderi R, Egan TP. 2019. Corn nitrogen management using NDVI and SPAD sensor-based data under conventional vs. reduced tillage systems. Journal of Plant Nutrition 42:2310-2322 DOI 10.1080/01904167.2019.1648686.

Errecart PM, Agnusdei MG, Lattanzi FA, Marino MA. 2012. Leaf nitrogen concentration and chlorophyll meter readings as predictors of tall fescue nitrogen nutrition status. Field Crops Research 129:46-58 DOI 10.1016/j.fcr.2012.01.008.

Goltsev VN, Kalaji HM, Paunov M, Baba W, Horaczek T, Mojski J, Kociel H, 
261

262

263

264

265

266

267

268

269

270

271

272

273

274

275

276

277

278

279

280

281

Allakhverdiev SI. 2016. Variable chlorophyll fluorescence and its use for assessing physiological condition of plant photosynthetic apparatus. Russian Journal of Plant Physiology 63:869-893 DOI 10.1134/S1021443716050058.

Guo J, Yang S, Gao L, Lu Z, Guo J, Sun Y, Kong Y, Ling N, Shen Q, Guo S. 2019. Nitrogen nutrient index and leaf function affect rice yield and nitrogen efficiency. Plant and Soil 445:7-21 DOI 10.1007/s11104-019-04076-z.

Horaczek T, Dabrowski P, Kalaji HM, Baczewska-Dabrowska AH, Pietkiewicz S, Stepien W, Gozdowski D. 2020. JIP-test as a tool for early detection of the macronutrients deficiency in Miscanthus plants. Photosynthetica 58:322-332 DOI 10.32615/ps.2019.177.

Hou W, Trankner M, Lu J, Yan J, Huang S, Ren T, Cong R, Li X. 2020. Diagnosis of nitrogen nutrition in rice leaves influenced by potassium levels. Frontiers in plant science 11:165 DOI 10.3389/fpls.2020.00165.

Huang J, He F, Cui K, Buresh RJ, Xu B, Gong W, Peng S. 2008. Determination of optimal nitrogen rate for rice varieties using a chlorophyll meter. Field Crop Research 105:70-80 DOI 10.1016/j.fcr.2007.07.006.

Jian Z, Wang F, Li Z, Chen Y, Ma X, Nie L, Cui K, Peng S, Lin Y, Song H, Li Y, Huang J. 2014. Grain yield and nitrogen use efficiency responses to $\mathrm{N}$ application in $B t(C r y l A b / A c)$ transgenic two-line hybrid rice. Field Crop Research 155:184-191 DOI 10.1016/j.fcr.2013.09.007.

Kalaji HM, Oukarroum A, Alexandrov V, Kouzmanova M, Brestic M, Zivcak M, Samborska IA, Cetner MD, Allakhverdiev SI, Goltsev V. 2014. Identification of nutrient 
282

283

284

deficiency in maize and tomato plants by in vivo chlorophyll a fluorescence measurements. Plant Physiology and Biochemistry 81:16-25 DOI 10.1016/J.PLAPHY.2014.03.029.

Kalaji HM, Dabrowski P, Cetner MD, Samborska IA, Lukasik I, Brestic M, Zivcak M, Tomasz H, Mojski J, Kociel H, Panchal BM. 2017. A comparison between different chlorophyll content meters under nutrient deficiency conditions. Journal of Plant Nutrition 40:1024-1034 DOI 10.1080/01904167.2016.1266623.

Kalaji HM, Rastogi A, Zivcak M, Brestic M, Daszkowska-Golec A, Sitko K, Alsharafa KY, Lotfi R, Stypinski P, Samborska IA, Cetner MD. 2018. Prompt chlorophyll fluorescence as a tool for crop phenotyping: An example of barley landraces exposed to various abiotic stress factors. Photosynthetica 56:953-961 DOI 10.1007/s11099-018-0766-z.

Khurana HS, Phillips SB, Singh B, Dobermann A, Sidhu AS, Singh Y, Peng S. 2007. Performance of site-specific nutrient management for irrigated, transplanted rice in Northwest India. Agronomy Journal 99:1436-1447 DOI 10.2134/agronj2006.0283.

Ku HH, Hayashi K, Agbisit R, Villegas-Pangga, G. 2016. Effect of rates and sources of nitrogen on rice yield, nitrogen efficiency, and methane emission from irrigated rice cultivation. Archives of Agronomy and Soil Science 63:1009-1022 DOI $10.1080 / 03650340.2016 .1255327$.

Li J, Yan J, Fei P, Song J, Li D, Ge C, Chen W. 2009. Responses of rice leaf thickness, SPAD readings and chlorophyll $\mathrm{a} / \mathrm{b}$ ratios to different nitrogen supply rates in paddy field. Field Crop Research 114:426-432 DOI 10.1016/j.fcr.2009.09.009.

Liu X, Zhang Y, Han W, Tang A, Shen J, Cui Z, Vitousek P, Erisman JW, Goulding K, 
303

304

305

306

307

308

309

310

311

312

313

314

315

316

317

318

319

320

321

322

323

Christie P, Fangmeier A, Zhang F. 2013. Enhanced nitrogen deposition over China. Nature 494:459-462 DOI 10.1038/nature11917.

Maiti D, Das DK. 2006. Management of nitrogen through the use of leaf colour chart (LCC) and soil plant analysis development (SPAD) in wheat under irrigated ecosystem. Archives of Agronomy and Soil Science 52:105-112 DOI 10.1080/03650340500460875.

Monostori I, Arendas T, Hoffman B, Galiba G, Gierczik K, Szira F, Vagujfalvi A. 2016. Relationship between SPAD value and grain yield can be affected by cultivar, environment and soil nitrogen content in wheat. Euphytica 211:103-112 DOI 10.1007/s10681-016-1741-z.

Msilini N, Essemine J, Zaghdoudi M, Harnois J, Lachhaal M, Ouerghi Z, Carpentier R. 2013. How does iron deficiency disrupt the electron flow in photosystem I of lettuce leaves? Journal of Plant Physiology 170:1400-1406 DOI 10.1016/j.jplph.2013.05.004.

Naus J, Prokopova J, Rebicek J, Spundova M. 2010. SPAD chlorophyll meter reading can be pronouncedly affected by chloroplast movement. Photosynthesis research 105:265-271 DOI 10.1007/s11120-010-9587-z.

Parvizi Y, Ronaghi A, Maftoun M, Karimian NA. 2004. Growth, nutrient status, and chlorophyll meter readings in wheat as affected by nitrogen and manganese. Communications in Soil Science and Plant Analysis 35:1387-1399 DOI 10.1081/CSS-120037553.

Peng S, Garcia FV, Laza RC, Cassman KG. 1993. Adjustment for specific leaf weight improves chlorophyll meters estimate of rice leaf nitrogen concentration. Agronomy Journal 85:987-990 DOI 10.2134/agronj1993.

Peng S, Buresh R, Huang J, Yang J, Zou Y, Zhong X, Wang G, Zhang F. 2006. Strategies 
324

325

326

327

328

329

330

331

332

333

334

335

336

337

338

339

340

341

342

343

344

for overcoming low agronomic nitrogen use efficiency in irrigated ricesystems in China. Field Crops Research 96:37-47 DOI 10.1016/j.fcr.2005.05.004.

Qiao J, Yang L, Yan T, Xue F, Zhao D. 2012. Nitrogen fertilizer reduction in rice production for two consecutive years in the Taihu Lake area. Agriculture, Ecosystems \& Environment 146:103-112 DOI 10.1016/j.agee.2011.10.014.

Ramesh K, Chandrasekaran B, Balasubramanian TN, Bangarusamy U, Sivasamy R, Sankaran N. 2002. Chlorophyll dynamics in rice (Oryza sativa) before and after flowering based on SPAD (chlorophyll) meter monitoring and its relation with grain yield. Journal of Agronomy and Crop Science 188:102-105 DOI 10.1046/j.1439-037X.2002.00532.x.

Redillas MCFR, Jeong JS, Strasser RJ, Kim YS, Kim JK. 2011. JIP analysis on rice (Oryza sativa cv Nipponbare) grown under limited nitrogen conditions. Journal of the Korean Society for Applied Biological Chemistry 54:827-832 DOI 10.1007/BF03253169.

Reyes JF, Correa C, Zúñiga J. 2017. Reliability of different color spaces to estimate nitrogen SPAD values in maize. Computers and Electronics in Agriculture 143:14-22 DOI 10.1016/j.compag.2017.09.032.

Rorie RL, Purcell LC, Mozaffari M, Karcher DE, King CA, Marsh MC, Longer DE. 2011. Association of "greenness" in corn with yield and leaf nitrogen concentration. Agronomy Journal 103:529-535 DOI 10.2134/agronj2010.0296.

Samborski SM, Tremblay N, Fallon E. 2009. Strategies to make use of plant sensors-based diagnostic information for nitrogen recommendations. Agronomy Journal 101:800-816 DOI 10.2134/agronj2008.0162Rx. 
345

346

347

348

349

350

351

352

353

354

355

356

357

358

359

360

361

362

363

364

365

Singh V, Singh B, Singh Y, Thind HS, Gupta RK. 2010. Need based nitrogen management using the chlorophyll meter and leaf colour chart in rice and wheat in South Asia: a review. Nutrient Cycling in Agroecosystems 88:361-380 DOI 10.1007/s10705-010-9363-7.

Tian Y, Yao X, Yang J, Cao W, Hannaway D, Zhu Y. 2011. Assessing newly developed and published vegetation indices for estimating rice leaf nitrogen concentration with ground-and space-based hyperspectral reflectance. Field Crops Research 120:299-310 DOI 10.1016/j.fcr.2010.11.002.

Tilman D, Balzer C, Hill J, Befort BL. 2011. Global food demand and the sustainable intensification of agriculture. Proceedings of the National Academy of Sciences of the United States of America 108:20260-20264 DOI 10.1073/pnas.1116437108.

Uddling J, Gelang-Alfredsson J, Piikki K, Pleijel H. 2007. Evaluating the relationship between leaf chlorophyll concentration and SPAD-502 chlorophyll meter readings. Photosynthesis Research 91:37-46 DOI 10.1007/s11120-006-9077-5.

Wang W, Lu J, Ren T, Li X, Su W, Lu M. 2012. Evaluating regional mean optimal nitrogen rates in combination with indigenous nitrogen supply for rice production. Field Crop Research 137:37-48 DOI 10.1016/j.fcr.2012.08.010.

Wang Y, Wang D, Shi P, Omasa K. 2014. Estimating rice chlorophyll content and leaf nitrogen concentration with a digital still color camera under natural light. Plant Methods 10:36 DOI 10.1186/1746-4811-10-36.

Xiong D, Chen J, Yu T, Gao W, Ling X, Li Y, Peng S, Huang J. 2015. SPAD-based leaf nitrogen estimation is impacted by environmental factors and crop leaf characteristics. 
Scientific Reports 5:13389 DOI 10.1038/srep13389.

367

368

369

370

371

372

373

374

375

376

377

378

379

380

381

382

383

384

385

386

Yang W, Peng S, Huang J, Sanico A, Boland R, Witt C. 2003. Using leaf color charts to estimate leaf nitrogen status of rice. Agronomy Journal 95:212-217 DOI 10.2134/agronj2003.2120.

Yang H, Li J, Yang J, Wang H, Zou J, He J. 2014. Effects of nitrogen application rate and leaf age on the distribution pattern of leaf SPAD readings in the rice canopy. PLoS ONE 9:e88421 DOI 10.1371/journal.pone.0088421.

Yu H, Wu H, Wang Z. 2010. Evaluation of SPAD and Dualex for in-season corn nitrogen status estimation. Acta Agronomica Sinica 36:840-847 DOI 10.1016/S1875-2780(09)60051-1.

Yuan Z, Ata-Ul-Karim ST, Cao Q, Lu Z, Cao W, Zhu Y, Liu X. 2016. Indicators for diagnosing nitrogen status of rice based on chlorophyll meter readings. Field Crop Research 185:12-20 DOI 10.1016/j.fcr.2015.10.003.

Zeng X, Han B, Xu F, Huang J, Cai H, Shi L. 2012. Effects of modified fertilization technology on the grain yield and nitrogen use efficiency of midseason rice. Field Crop Research 137:203-212 DOI 10.1016/j.fcr.2012.08.012.

Zhang H, Xue Y, Wang Z, Yang J, Zhang J. 2009. An alternate wetting and moderate soil drying regime improves root and shoot growth in rice. Crop Science 49:2246-2260 DOI 10.2135/cropsci2009.02.0099.

Zhou G, Yin X. 2017. Assessing nitrogen nutritional status, biomass and yield of cotton with NDVI, SPAD and petiole sap nitrate concentration. Experimental Agriculture 54:1-18 DOI $10.1017 / \mathrm{S} 0014479717000229$. 
387 Ziadi N, Brassard M, Belanger G, Claessens A, Tremblay N, Cambouris AN, Nolin MC,

388 Parent LE. 2008. Chlorophyll measurements and $\mathrm{N}$ nutrition index for the evaluation of corn N status. Agronomy Journal 100:1264-1273 DOI 10.2134/agronj2008.0016. 


\section{Table 1 (on next page)}

Leaf SPAD readings and recommended $\mathrm{N}$ rates of the verification experiments at tillering stage 
1

2 Table 1 Leaf SPAD readings and recommended $N$ rates of the verification experiments at

$3 \quad$ tillering stage.

\begin{tabular}{|c|c|c|c|c|}
\hline \multirow{3}{*}{ Treatments } & \multicolumn{2}{|c|}{ Experiment 1} & \multicolumn{2}{|c|}{ Experiment 2} \\
\hline & SPAD & $\mathrm{N}$ rate & SPAD & $\mathrm{N}$ rate \\
\hline & & $\mathrm{kg} \mathrm{N} \mathrm{ha}^{-1}$ & & $\mathrm{~kg} \mathrm{~N} \mathrm{ha}^{-1}$ \\
\hline $\mathrm{CK}$ & $28.7 \pm 0.6 \mathrm{c}$ & $0 \pm 0 \mathrm{c}$ & $28.6 \pm 0.9 \mathrm{c}$ & $0 \pm 0 \mathrm{c}$ \\
\hline $\mathrm{FP}$ & $36.6 \pm 1.4 \mathrm{a}$ & $45.0 \pm 0.8 \mathrm{~b}$ & $37.6 \pm 1.7 \mathrm{a}$ & $45.0 \pm 1.2 \mathrm{a}$ \\
\hline OPT & $33.0 \pm 1.1 \mathrm{~b}$ & $46.8 \pm 0.9 \mathrm{a}$ & $32.6 \pm 1.3 \mathrm{~b}$ & $35.9 \pm 1.0 \mathrm{~b}$ \\
\hline
\end{tabular}

4

5 


\section{Table 2 (on next page)}

Leaf SPAD readings and recommended $\mathrm{N}$ rates of the verification experiments at booting stage 
1 Table 2 Leaf SPAD readings and recommended $\mathbf{N}$ rates of the verification experiments at

2 booting stage.

\begin{tabular}{ccccc}
\hline & \multicolumn{2}{c}{ Experiment 1} & \multicolumn{2}{c}{ Experiment 2 } \\
\cline { 2 - 5 } Treatments & SPAD & $\begin{array}{c}\text { N rate } \\
\mathrm{kg} \mathrm{N} \mathrm{ha}^{-1}\end{array}$ & SPAD & $\begin{array}{c}\text { N rate } \\
\mathrm{kg} \mathrm{N} \mathrm{ha}^{-1}\end{array}$ \\
\hline CK & $28.6 \pm 1.1 \mathrm{~b}$ & $0 \pm 0 \mathrm{~b}$ & $30.9 \pm 0.7 \mathrm{~b}$ & $0 \pm 0 \mathrm{c}$ \\
FP & $35.9 \pm 0.8 \mathrm{a}$ & $45.0 \pm 0.4 \mathrm{a}$ & $35.5 \pm 1.1 \mathrm{a}$ & $45.0 \pm 1.0 \mathrm{~b}$ \\
OPT & $36.8 \pm 1.2 \mathrm{a}$ & $44.7 \pm 0.5 \mathrm{a}$ & $34.7 \pm 0.9 \mathrm{a}$ & $51.6 \pm 1.2 \mathrm{a}$ \\
\hline
\end{tabular}

3 


\section{Table 3(on next page)}

Grain yield, $\mathrm{N}$ rates and $\mathrm{N}$ use efficiency of the verification experiments 
1 Table 3 Grain yield, $\mathbf{N}$ rates and $\mathbf{N}$ use efficiency of the verification experiments.

\begin{tabular}{cccccc}
\hline \multirow{2}{*}{ Treatments } & & $\begin{array}{c}\text { Grain yield } \\
\mathrm{kg} \mathrm{ha}^{-1}\end{array}$ & $\begin{array}{c}\text { N rate } \\
\mathrm{kg} \mathrm{ha}^{-1}\end{array}$ & $\begin{array}{c}\text { NAE } \\
\mathrm{kg} \mathrm{kg}^{-1}\end{array}$ & $\begin{array}{c}\text { PFPN } \\
\mathrm{kg} \mathrm{kg}^{-1}\end{array}$ \\
\hline \multirow{2}{*}{ Experiment 1 } & FP & $1951 \pm 136 \mathrm{~b}$ & $0 \pm 0 \mathrm{c}$ & - & - \\
& OPT & $8733 \pm 245 \mathrm{a}$ & $180.0 \pm 0 \mathrm{a}$ & $37.7 \pm 1.1 \mathrm{~b}$ & $48.5 \pm 0.9 \mathrm{~b}$ \\
& CK & $3394 \pm 208 \mathrm{~b}$ & $0 \pm 0 \mathrm{c}$ & - & $51.4 \pm 0.7 \mathrm{a}$ \\
Experiment 2 & FP & $6989 \pm 368 \mathrm{a}$ & $180.0 \pm 0 \mathrm{a}$ & $20.0 \pm 0.8 \mathrm{~b}$ & $38.8 \pm 1.3 \mathrm{~b}$ \\
& OPT & $6756 \pm 404 \mathrm{a}$ & $152.5 \pm 1.8 \mathrm{~b}$ & $22.0 \pm 1.1 \mathrm{a}$ & $44.3 \pm 1.8 \mathrm{a}$ \\
\hline
\end{tabular}

2 
Figure 1

Temperature and precipitation during the rice-growing stage

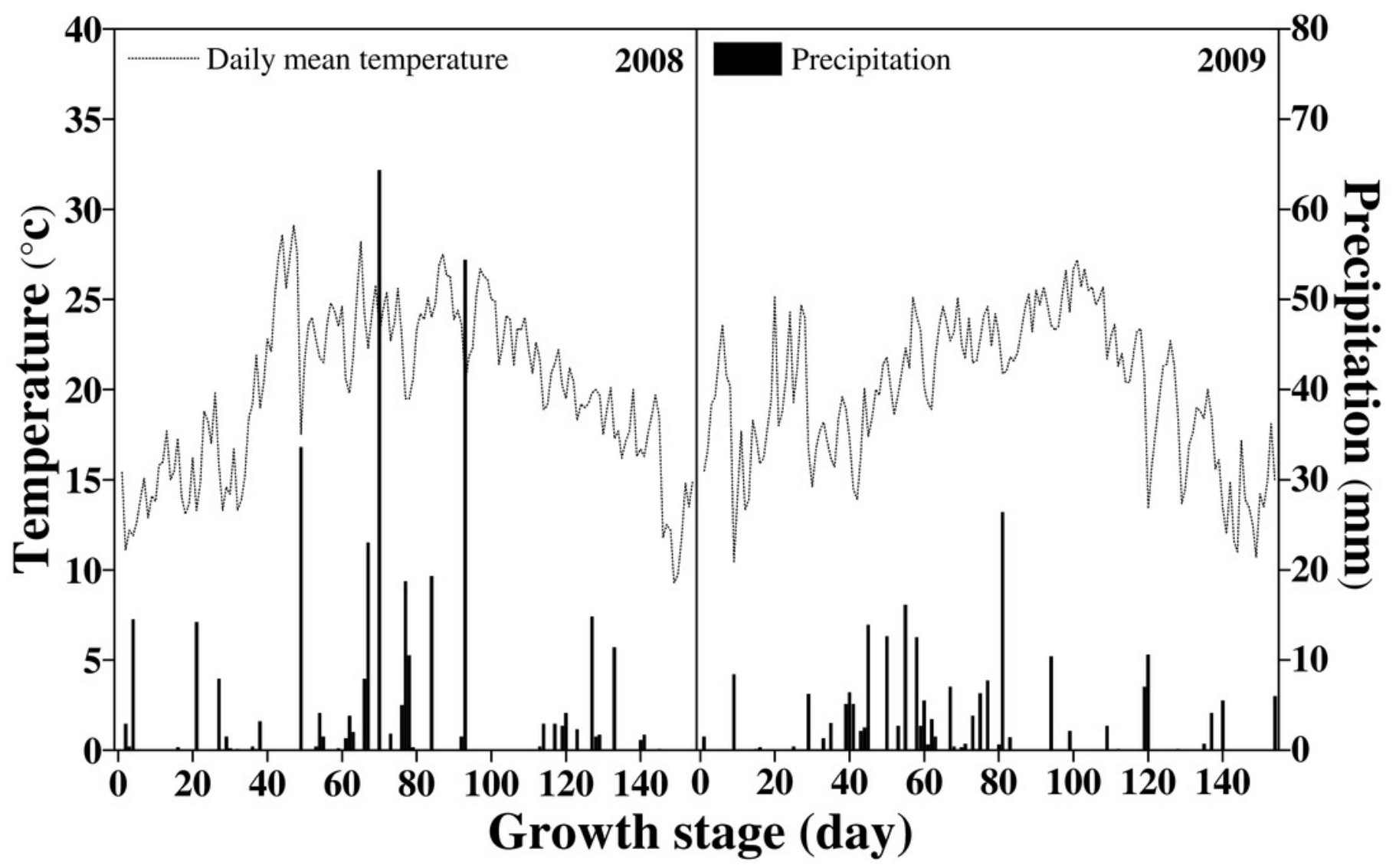


Figure 2

Temperature and precipitation during the rice-growing stage

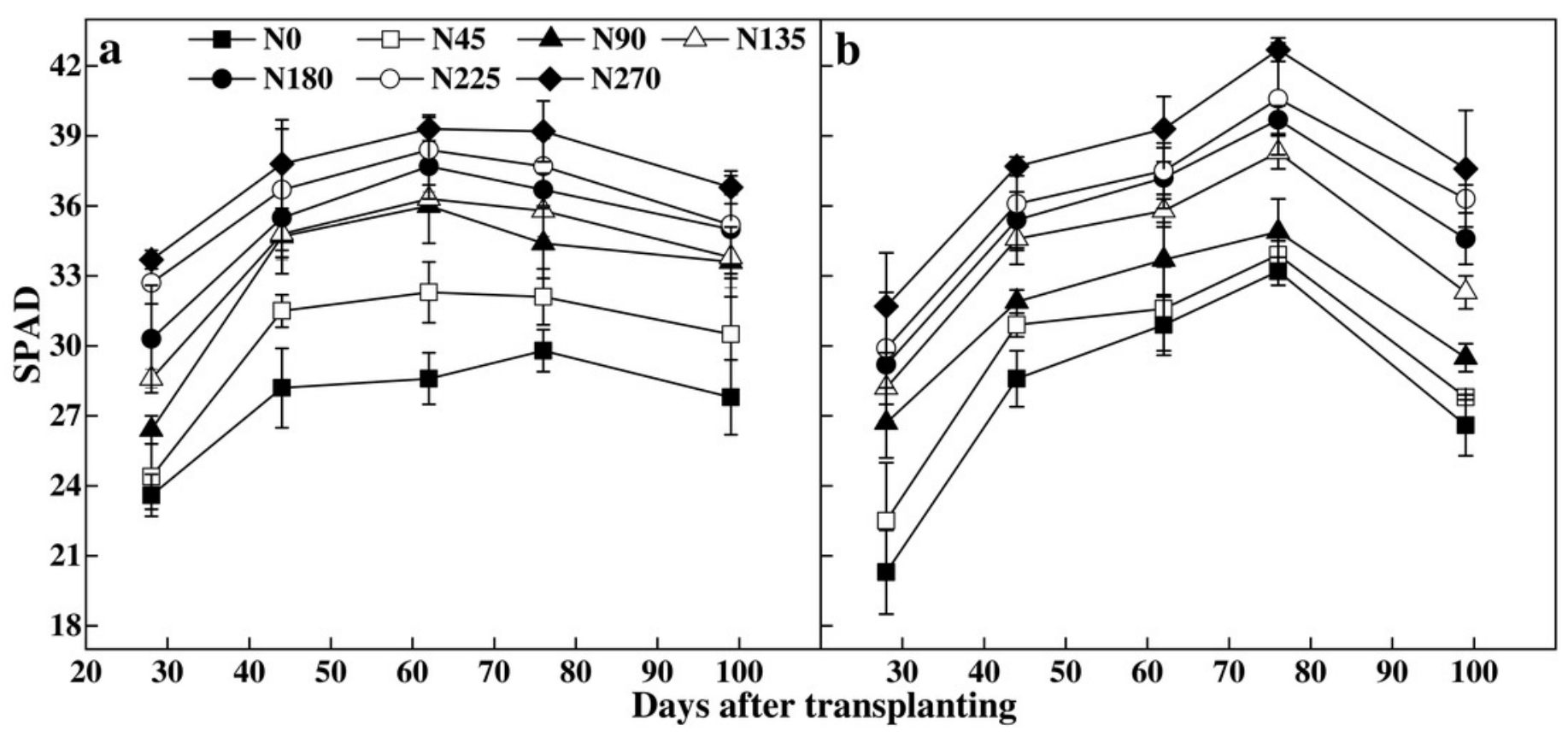


Figure 3

Relationships between $\mathrm{N}$ rates with SPAD at tillering ( $\mathrm{a}$ and $\mathrm{b}$ ) and booting stage ( $\mathrm{c}$ and d)
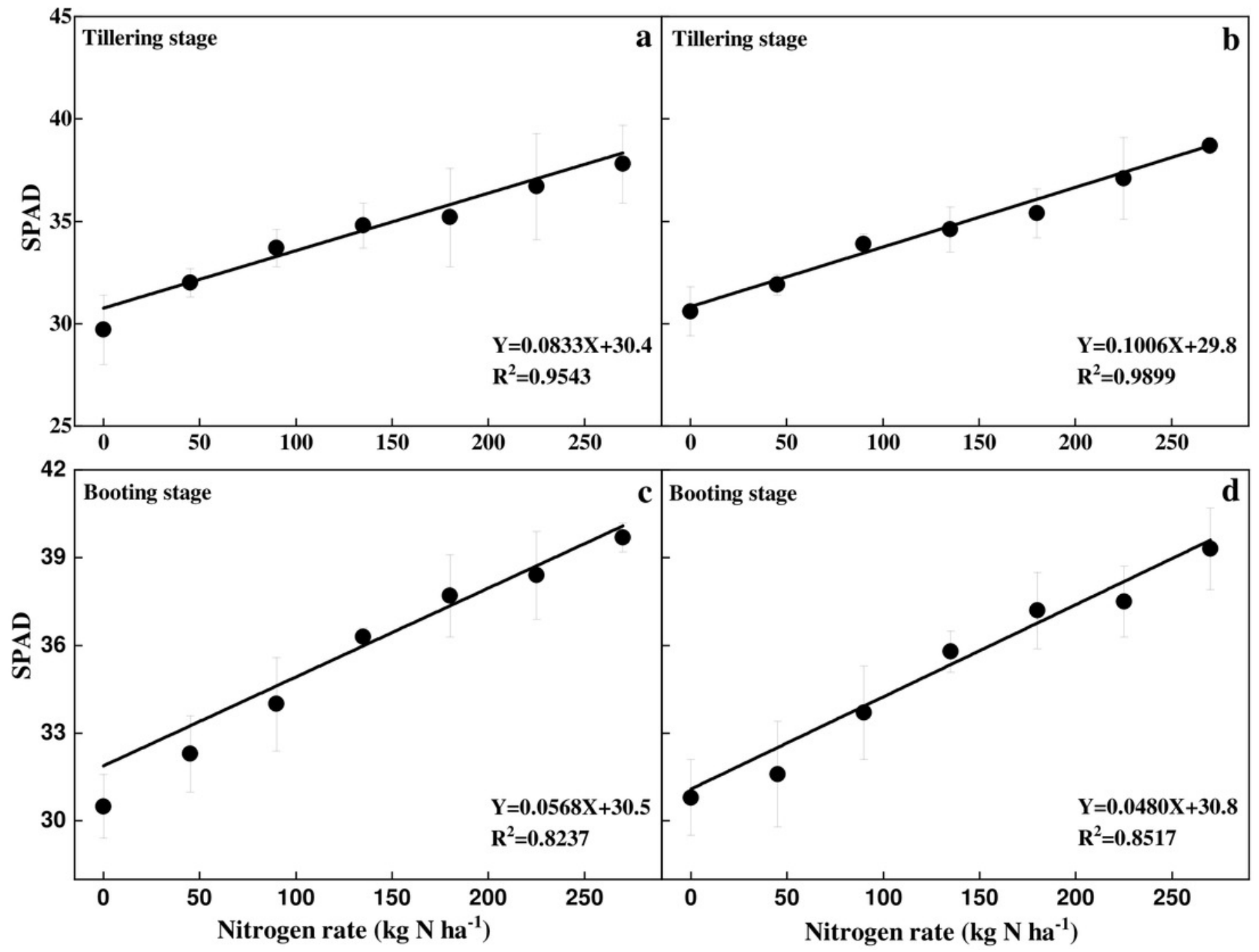
Figure 4

Effects of different $\mathrm{N}$ rates on grain yield of rice

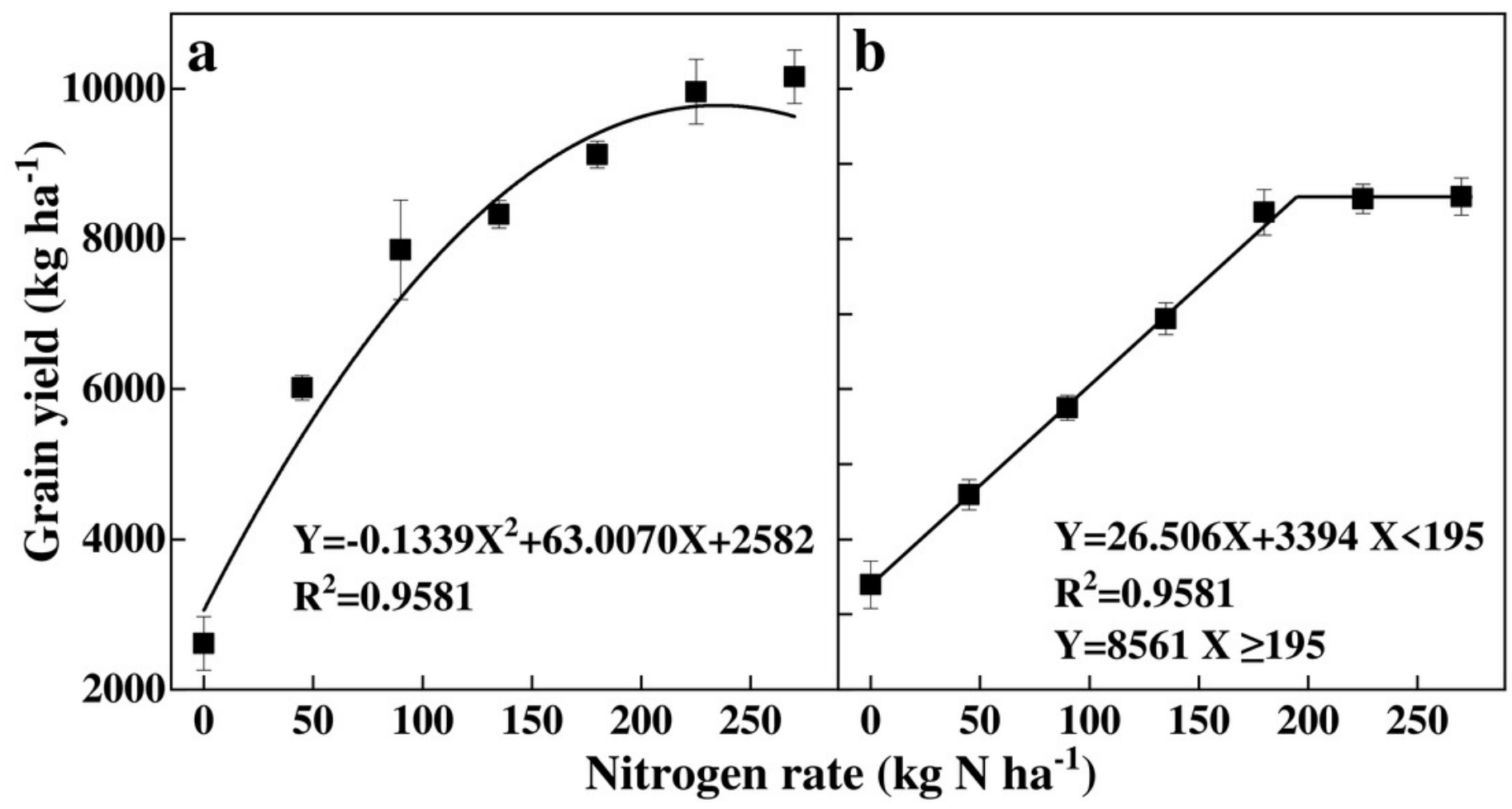

